\title{
Steroid-binding proteins in follicular fluid and peripheral plasma from pigs, cows and sheep
}

\author{
B. Cook*, R. H. F. Hunter† and Anne S. L. Kelly* \\ * Department of Steroid Biochemistry, University of Glasgow, Royal Infirmary, Glasgow G4 OSF, \\ and $\uparrow$ School of Agriculture, University of Edinburgh, West Mains Road, Edinburgh EH9 3JG, U.K.
}

\begin{abstract}
Summary. No unusual steroid-binding proteins that might react with the oocyte or its investments could be detected in follicular fluid. Corticosteroid-binding globulin occurred in follicular fluid from pigs, sheep and cows, and sex hormone-binding globulin occurred in follicular fluid from sheep and cows. The bulk of the steroid in follicular fluid is bound to albumin with low affinity, indicating that steroid molecules can readily be released, and oestrogen can react with the oocyte and granulosa cells in a manner analogous to that demonstrated for target cells bathed with interstitial fluid. Pigs lack a sex-hormone binding globulin in blood plasma and, hence, in follicular fluid. Because no proteins exist in follicular fluid that would compete with antibodies to bind steroids, direct radioimmunoassay of follicular steroids appears to be a valid technique.
\end{abstract}

\section{Introduction}

Ovarian oocytes appear to need high concentrations of oestrogen in their bathing follicular fluid before they can resume nuclear and cytoplasmic maturation (Hunter, Cook \& Baker, 1976). The relative abundance of different steroids changes markedly as ovulation approaches and concentrations rise to such a degree that some mechanism must exist to maintain steroids in solution (Baird \& Fraser, 1975). Association of steroids with proteins is an obvious means of maintaining homogeneity, but few investigations of steroid-protein interactions in follicular fluid appear to have been reported, although Takikawa (1966) showed that in bovine follicles oestradiol was largely bound to albumin. If such steroid-protein interactions are widespread, a number of questions arise. Do the oocyte or its investments need some kind of follicular oestrogen-protein complex (comparable to intracellular oestrogen-receptor complexes) to facilitate maturation, or is the steroid-protein association of such low affinity that the steroid can be liberated to interact freely with the oocyte and other cells within the follicle? Are steroid-binding globulins from blood (sex-hormone binding globulin-SHBG and corticosteroid-binding globulin--CBG) present in follicular fluid? If so, are they of any significance in modulating steroid availability within the follicle? This paper describes experiments to investigate the nature of the association of steroids and proteins in porcine follicular fluid which may help to answer some of these questions. Samples of ovine and bovine follicular fluid were studied for comparison.

\section{Materials and Methods}

\section{Animals}

Follicular fluid samples were obtained from 33 pigs at laparotomy as previously described (Hunter et al., 1976). Most of these samples were obtained on Days 17, 20 and 21 of the oestrous cycle (i.e. during the early or late follicular phase), but a few were from Days 18 and 19. Peripheral plasma samples were obtained from blood withdrawn from the ear veins of the pigs at various stages of the oestrous cycle. Some samples of follicular fluid from sheep and cows were obtained from ovaries removed after slaughter, but the reproductive histories of these animals were not known. Fluids from small bovine follicles and normal ovine follicles were pooled to give samples large 
enough for investigation. Samples of ovine and bovine peripheral plasma were obtained from blood collected from the jugular veins. In general, blood samples and follicular fluid samples were not obtained from the same animal.

\section{Chemicals}

The Radiochemical Centre, Amersham, U.K., supplied $\left[1,2,6,7-^{3} \mathrm{H}\right]$ progesterone (sp. act. $80 \mathrm{Ci} / \mathrm{mmol}$ ), $\left[2,4,6,7-{ }^{3} \mathrm{H}\right]$ oestradiol (sp. act. $83 \mathrm{Ci} / \mathrm{mmol}$ ), $\left[1,2,4,5,6,7-{ }^{3} \mathrm{H}\right] 5 \alpha$-dihydrotestosterone (sp. act. $130 \mathrm{Ci} / \mathrm{mmol}$ ) and $\left[1,2,6,7-{ }^{3} \mathrm{H}\right]$ cortisol (sp. act. $82 \mathrm{Ci} / \mathrm{mmol}$ ). New England Nuclear, Boston, U.S.A., supplied $\left[1,2,6,7-{ }^{3} \mathrm{H}\right]$ testosterone (sp. act. $85 \mathrm{Ci} / \mathrm{mmol}$ ). All of these radioactive steroids were purified chromatographically before use. Progesterone, $5 \alpha$-dihydrotestosterone, testosterone and cortisol were obtained from Steraloids, Wilton, New Hampshire, U.S.A., and oestradiol from Koch-Light Laboratories, Ltd, Colnbrook, U.K. All other chemicals were of AR grade.

\section{Radioimmunoassay of steroids}

Oestradiol, progesterone and testosterone in follicular fluid were measured by radioimmunoassay. Antisera were raised in sheep against 6-oxo-oestradiol carboxymethyloxime, 11 $\alpha$-hydroxyprogesterone hemisuccinate and testosterone-3-carboxymethyloxime, each coupled to bovine serum albumin. Cross-reactions were $8 \%$ with oestrone for the anti-oestradiol serum; $4 \%$ with 11 deoxycorticosterone, $1.5 \%$ with $17 \alpha$-hydroxyprogesterone and $1 \%$ with $20 \alpha$-hydroxypregn-4-en-3one for the anti-progesterone serum; and $85 \%$ with $5 \alpha$-dihydrotestosterone, $3 \%$ with $5 \alpha$-androstane- $3 \alpha, 17 \beta$-diol and $2 \%$ with androstenedione for the anti-testosterone serum. All other steroids that were tested gave $<1 \%$ cross-reaction. Steroids were determined in follicular fluid before and after hydrolysis with a non-specific protease from Streptomyces griseus (Sigma London, Catalogue No. P5005). Preliminary experiments to determine optimum enzyme concentration were conducted with azoalbumin (Sigma London, Catalogue No. A2382) as substrate (Tomarelli, Charney \& Harding, 1949). For steroid determination, with and without enzyme treatment, follicular fluid was diluted 100 -fold with distilled water, and two different volumes, each in duplicate (4 samples), were assayed. This technique established that the response of the sample paralleled the response of the standard. For hydrolysis of any steroid-binding proteins that might interfere with steroid binding to the antiserum (Hasler et al., 1975), samples were incubated for $2 \mathrm{~h}$ at $37^{\circ} \mathrm{C}$ with $200 \mu \mathrm{l}$ protease solution containing $2 \mathrm{mg} / \mathrm{ml}$. Tubes containing known amounts of steroid for the standard curve were similarly incubated to minimize non-specific effects due to the enzyme treatment. At the end of this period, all enzyme-treated samples were put in a boiling water bath for $5 \mathrm{~min}$. Following denaturation of the enzyme, labelled steroid and antiserum were added to the sample and the volume was adjusted to $1 \mathrm{ml}$, as it was also in the direct assay. For the directly assayed and the enzyme-treated samples, incubation with labelled steroid and antiserum was for a period of at least $2 \mathrm{~h}$, and antibodybound and free steroid were then separated with dextran-coated charcoal (Hotchkiss, Atkinson \& Knobil, 1971).

\section{Gel filtration}

High affinity steroid-binding proteins from follicular fluid and plasma were assayed by gel filtration on Sephadex LH-20 by the method of Ginsburg, Greenstein, MacLusky, Morris \& Thomas (1974). Both plasma and follicular fluid were diluted 20 -fold for assay, and $250 \mu 1$ aliquots were incubated with labelled steroid at a concentration of $5 \mathrm{~nm}$ for $2 \mathrm{~h}$ at $0^{\circ} \mathrm{C}$. A duplicate sample was incubated similarly but with the addition of $500 \mathrm{~nm}$ unlabelled steroid. Samples were filtered through columns ( $60 \mathrm{~mm}$ long, i.d. $7 \mathrm{~mm}$ ) and radioactivity was counted as described by Cowan, Cowan, Giles \& Grant (1976). The difference in total radioactive counts between the two eluted protein fractions gave a measure of specific steroid binding. Samples were tested in this way for protein association with $5 \alpha$-dihydrotestosterone, cortisol and oestradiol. Human CBG cross-reacts with testosterone but not with $5 \alpha$-dihydrotestosterone, and the latter steroid was therefore used to detect SHBG with minimum CBG interference (Corvol, Chrambach, Rodbard \& Bardin, 1971). 


\section{Steady-state polyacrylamide gel electrophoresis}

The technique of Ritzén, French, Weddington, Nayfeh \& Hansson (1974) was used, because it allows the detection of high- and low-affinity binding proteins. Follicular fluid or plasma was diluted 10 -fold with $10 \%$ aqueous glycerol and $500 \mu \mathrm{l}$ samples were incubated with labelled steroid $(5,10$ or $20 \mathrm{nM}$ ) for $2 \mathrm{~h}$ at $0^{\circ} \mathrm{C}$. Duplicate samples were incubated similarly, but with the addition of 50 times the concentration of unlabelled steroid as described above for gel filtration. Labelled steroid ( 2 or $5 \mathrm{nM}$ ) was incorporated into $7 \%$ polyacrylamide gels to which the incubated sample $(50 \mu \mathrm{l})$ was transferred. Unlabelled steroid ( 50 times the concentration of labelled steroid) was incorporated into gels for those samples that had already been incubated with unlabelled steroid. The gels were run, sliced and counted as described by Cowan et al. (1976), except that the current was reduced to $1 \mathrm{~mA}$ per gel. Representative samples of follicular fluid and plasma were scanned for protein interaction with progesterone, cortisol, oestradiol, testosterone and $5 \alpha$-dihydrotestosterone.

\section{Polyacrylamide-gel electrophoresis (for receptors)}

A small number of porcine follicular fluid samples was examined for the presence of oestrogen receptor-like proteins using $3.25 \%$ polyacrylamide gels as described by Hansson et al. (1974). Follicular fluid was diluted 10 -fold and incubated for $2 \mathrm{~h}$ at $0^{\circ} \mathrm{C}$ with $5 \mathrm{~nm}$-tritiated oestradiol. Duplicate samples were treated similarly, but oestradiol $(500 \mathrm{nM})$ was added to the incubation medium to saturate high-affinity binding proteins. The gels were run using a current of $0.5 \mathrm{~mA} /$ tube. Positive controls were run concurrently to establish the validity of the method. Cytosol was prepared from excised prostate glands of rats castrated $24 \mathrm{~h}$ earlier (Cowan et al., 1976), and portions of cytosol were incubated with tritiated $5 \alpha$-dihydrotestosterone to label the androgen receptor protein. The separation of this protein during the development of the gel indicated the satisfactory performance of the method. Gels were sliced and counted as described above.

\section{Protein determinations}

The amount of protein present in all samples of follicular fluid and plasma was determined by the method of Lowry, Rosebrough, Farr \& Randall (1951) with bovine serum albumin as the standard.

\section{Results}

Protein concentrations in follicular fluid are given in Table 1. For all three species, they fell within the normal range of protein concentration in plasma. In pigs, protein concentration in follicular fluid did not change significantly with the day of the oestrous cycle between Days 17 and 21 .

The results of the radioimmunoassay experiment are presented in Table 2. Protease treatment did not change the amount of oestradiol detected in the plasma (Table 2). Regression analysis of

Table 1. Protein concentrations $(\mathrm{mg} / \mathrm{ml})$ in blood plasma and follicular fluid obtained at laparotomy or autopsy from pigs, sheep and cows

\begin{tabular}{|c|c|c|c|c|c|c|}
\hline \multirow[b]{2}{*}{ Species } & \multicolumn{2}{|c|}{ Plasma* } & \multirow{2}{*}{$\begin{array}{l}\text { Follicle } \\
\text { diam. } \\
(\mathrm{mm})\end{array}$} & \multicolumn{2}{|c|}{ Follicular fluid } & \multirow{2}{*}{$\begin{array}{l}\text { No. of } \\
\text { samples }\end{array}$} \\
\hline & Mean & Normal range & & Mean & Observed range & \\
\hline Pig & 80 & $60-100$ & $6-10 \dagger$ & 80 & $61-100$ & 33 \\
\hline Cow & 68 & $52-84$ & $5-14$ & 70 & $45-85$ & 8 \\
\hline \multirow[t]{2}{*}{ Sheep } & 66 & $47-77$ & $4-8 \ddagger$ & 64 & $53-75$ & 4 \\
\hline & & & $>15 \S$ & 96 & $93-103$ & 3 \\
\hline
\end{tabular}

\footnotetext{
* Values from Clinical Biochemistry Laboratory, Glasgow University Veterinary School; courtesy of Dr T. A. Douglas.

$\dagger$ Obtained between Days 17 and 20 of the oestrous cycle.

$\ddagger$ Pooled for analysis.

$\S$ Cystic.
} 
Table 2. The concentration of oestrogen and progesterone $(\mathrm{pg} / \mu \mathrm{l})$ in follicular fluid obtained at laparotomy or autopsy from pigs, sheep and cows

\begin{tabular}{|c|c|c|c|c|c|c|}
\hline \multirow[b]{2}{*}{ Species } & \multirow[b]{2}{*}{ Follicle type } & \multirow{2}{*}{$\begin{array}{l}\text { No. of } \\
\text { samples }\end{array}$} & \multicolumn{2}{|c|}{ Oestrogen } & \multicolumn{2}{|c|}{ Progesterone } \\
\hline & & & Untreated & Protease-treated & Untreated & Protease-treated \\
\hline \multirow[t]{3}{*}{ Pig } & Day 17 & 6 & $83(15-242)$ & $108(25-257)$ & $112(8-540)$ & $109(15-463)$ \\
\hline & Day 20 & 8 & $455(113-838)$ & $529(108-1350)$ & $481(22-1142)$ & $584(20-1522)$ \\
\hline & Day 21 & 9 & $20(3-36)$ & $33(4-85)$ & $181(22-491)$ & $258(21-571)$ \\
\hline Cow & $5-14 \mathrm{~mm}$ & 8 & $56(2-180)$ & $69(1-203)$ & $45(0-195)$ & $68(0-176)$ \\
\hline \multirow[t]{2}{*}{ Sheep } & Normal pools & 4 & $29(21-39)$ & $30(28-33)$ & $82(42-152)$ & $144(60-338)$ \\
\hline & Cystic follicles & 3 & $28(0-84)$ & $20(0-60)$ & $1518(1150-1762)$ & $1827(1155-2361)$ \\
\hline
\end{tabular}

Values are means with the range in parentheses.

protease-treated values on directly assayed values for 33 samples of porcine follicular fluid gave a slope of 1.18 and an intercept of $-7 \mathrm{pg} / \mu \mathrm{l}$; the correlation coefficient was 0.95 . Similar analysis of the results of the progesterone radioimmunoassays of porcine follicular fluid (Table 2) led to similar conclusions: the slope was $1 \cdot 12$, the intercept $47 \mathrm{pg} / \mu \mathrm{l}$ and the correlation coefficient 0.98 . For oestradiol and progesterone, therefore, the two methods of assay gave essentially the same results, showing that the proteins in follicular fluid did not interfere with antibody-steroid reactions in radioimmunoassay. For 17-hydroxyandrogens the results are less complete. Androgens were detected in many samples of follicular fluid, but in low concentrations. Because such measurements were made at the low end of the standard curve, they were not precise. Better estimates of androgen concentration could have been obtained for a greater number of samples if measurements had been made with less dilution of the follicular fluid, but not enough sample was available to do this. Thus, protease treatment did not appear to release protein-bound androgen, but the evidence is much weaker than that for oestradiol and progesterone.

The gel filtration experiments showed that follicular fluid and plasma samples contained a cortisol-binding protein, but no macromolecule that bound oestradiol, $5 \alpha$-dihydrotestosterone or progesterone. Macromolecular binding of $5 \alpha$-dihydrotestosterone was demonstrated with this system in human plasma samples which contain SHBG. Therefore, if oestradiol or $5 \alpha$-dihydroxytestosterone bind to porcine, bovine or ovine proteins, they do so with relatively low affinity. The uptake of $\left[{ }^{3} \mathrm{H}\right]$ cortisol was good and the inhibition ( $\%$ of uptake \pm S.E.M.) of this binding by unlabelled cortisol for the different samples was:- porcine plasma, $39 \pm 10(n=6)$; porcine follicular fluid, $56 \pm 4(n=18)$; bovine plasma $69(n=1)$; bovine follicular fluid, $72 \pm 6(n=5)$; ovine plasma, $64 \pm 12(n=4)$; and ovine follicular fluid, $58(n=1)$. Thus, there is clear evidence for cortisol-binding to a macromolecule, with the suggestion that this binding is weaker in porcine samples.

The results of the steady-state polyacrylamide gel electrophoresis (Ritzén et al., 1974) are shown in Text-fig. 1. Porcine plasma and follicular fluid behave in an essentially similar manner; CBG is present and binds cortisol and some progesterone, albumin binds more progesterone than cortisol, SHBG is not present and oestradiol and $5 \alpha$-dihydrotestosterone are bound only to albumin. In sheep, in which a SHBG exists, some $5 \alpha$-dihydrotestosterone became bound to this protein in plasma and follicular fluid, but this binding must be of relatively low affinity because an androgen-protein association was not detected with columns of Sephadex LH-20. Albumin binding of androgen also occurred but oestradiol interacted little with the testosterone-binding globulin, and became bound only to albumin. The situation in cows is the same as that in sheep. Free oestradiol, because it is phenolic, migrated in the electric field and a true steady state therefore does not exist for this steroid. In cows and sheep, patterns of binding for cortisol and progesterone were the same as those shown for pigs (Text-fig. 1). The pattern of steroid binding in porcine follicular fluid did not change between Days 17 and 21 of the cycle.

The second method of polyacrylamide gel electrophoresis (Hansson et al., 1974) showed no oestrogen-binding components in porcine follicular fluid on Days 17 or 21 comparable to intracellular receptor proteins. The method was functional because androgen receptors were detected in the castrated rat prostatic cytosol. 
The radioimmunoassay results demonstrate the absence of a protein in follicular fluid in any appreciable quantity that had a high affinity for steroid, since very little more oestrogen was measurable when all proteins had been digested. Steroid-protein complexes with an affinity constant greater than that of steroid-antibody complexes, i.e. $10^{-8}$ to $10^{-10} \mathrm{M}$, were not revealed. Anti-steroid antibodies will not strip steroid from intracellular receptor proteins and this property has been utilized to remove free steroid from a solution containing steroid-receptor complexes (Castaneda \& Liao, 1975). However, steroid concentrations in protease-treated fluids (Table 2) are marginally greater than those in untreated fluids. We found the slopes of the regression lines to be greater than 1.0 which could be taken as evidence for small amounts of high-affinity steroid-protein complex. Electrophoresis in $3.5 \%$ polyacrylamide gels did not reveal any such proteins, although the system was adjusted to detect steroid-receptor complexes and did so in control prostatic cytosol in which total protein concentration was, admittedly, much higher than it was in diluted samples of follicular fluid. The small differences in results between the two radioimmunometric techniques are believed to be due to non-specific factors, because no unexplained steroid binding was seen after electrophoresis in $7 \%$ polyacrylamide gels. McNatty et al. (1976) reached similar conclusions in a study of human follicular fluid. They showed that, for a range of steroids, radioimmunoassay gave the same values with or without solvent extraction of the samples. Enzymatic hydrolysis and solvent extraction have similar results in that they both lead to protein denaturation and allow determination of total steroid.

Andersen et al. (1976) demonstrated that the lower the molecular weight of a serum protein, the less likely it was to be excluded from follicular fluid. Human CBG has an approximate molecular weight of 52,000 , human SHBG of 100,000 and serum albumin of 68,000 . Proteins this size appear to have essentially free access to follicular fluid from serum. Indeed, Andersen et al. (1976) present evidence that such proteins might even be relatively concentrated in follicular fluid. The demonstration of the presence of these macromolecules in follicular fluid by gel filtration and by electrophoresis on $7 \%$ polyacrylamide gels is therefore consistent with their observations.

We have shown that primary oocytes could be shed from porcine Graafian follicles if HCG was injected in the mid-follicular phase of the oestrous cycle (Hunter et al., 1976) and an increase in oestrogen concentration was suggested to be a prime factor in facilitating oocyte maturation within follicles allowed to ovulate spontaneously. However, the results reported here suggest that steroidprotein complexes of high affinity are not mediators of granulosa-oocyte interactions, since no such proteins occurred in follicular fluid that were not found in blood plasma. SHBG has such a limited distribution from species to species (Corvol \& Bardin, 1973) that it is unlikely to have any fundamental role in oocyte maturation even though it appears in follicular fluid. Although some of the progesterone in follicular fluid may be bound to CBG, much of this steroid, together with oestradiol in porcine, ovine and bovine follicular fluid, is bound with low affinity to albumin. Since steroids can readily dissociate from this protein, there is no reason to suppose that any effect oestrogen may have on oocytes need be mediated by a process different from the interaction of this steroid with cytoplasmic receptors such as those described in other cells of the follicle (Richards, 1975).

Sex-steroid molecules in porcine follicular fluid are bound to macromolecules only weakly, and they are therefore able to react with target cells in the follicle in a manner analogous to that described for target cells bathed with interstitial fluid.

We thank Sheila K. Cowan and R. Nichol for help with these experiments, and R. A. Cowan and J. K. Grant for useful discussions. The Wellcome Trust and the Ford Foundation provided partial financial support.

\section{References}

ANDersen, M.M., Krøll, J., Byskov, A.G. \& FABer, M. (1976) Protein composition in the fluid of individual bovine follicles. J. Reprod. Fert. 48, 9-15.
BaIRD, D.T. \& Fraser, I.S. (1975) Concentration of oestrone and oestradiol in follicular fluid and ovarian venous blood of women. Clin. Endocr. 4, 643-647. 
Castaneda, E. \& Liao, S. (1975) The use of antisteroid antibodies in the characterization of steroid receptors. J. biol. Chem. 250, 883-888.

Corvol, P. \& BARdin, C.W. (1973) Species distribution of testosterone-binding globulin. Biol. Reprod. 8, 277-282.

Corvol, P.l., Chrambach, A., Rodbard, D. \& Bardis, C.W. (1971) Physical properties and binding capacity of testosterone-estradiol-binding globulin in human plasma determined by polyacrylamide gel electrophoresis. J. biol. Chem. 246, 34353443.

Cowan, R.A., Cowan, S.K., Giles, C.A. \& Grant, J.K. (1976) Prostatic distribution of sex hormone-binding globulin and cortisol-binding globulin in benign hyperplasia. $J$. Endocr. 71, 121131.

EDWARDS, R.G. (1974) Follicular fluid. J. Reprod. Fert. 37, 189-219.

Ginsburg, M., Greenstein, B.D., Maclusky, N.J., Morris, E.D. \& Thomas, P.J. (1974) An improved method for the study of high-affinity steroid binding: oestradiol binding in brain and pituitary. Steroids 23, 773-792.

Hansson, V., Mclean, W.S., Smith, A.A., Tindall, O.J., Weddington, S.C., NaYfeh, S.N., French, F.S. \& RitzÉn, E.M. (1974) Androgen receptors in rat testis. Steroids 23, 823-832.

Hasler, M.J., Painter, K. \& Niswender, G.D. (1976) An ${ }^{125}$ I-labeled cortisol radioimmunoassay in which serum binding proteins are enzymatically denatured. Clin. Chem. 22, 1850-1854.
Hotchkiss, J., Atrinson, L.E. \& Knobil, E. (1971) Time course of serum estrogen and luteinizing hormone concentrations during the menstrual cycle of the rhesus monkey. Endocrinology 89, 177-183.

HuNTER, R.H.F., COOK, B. \& BAKER, T.G. (1976) Dissociation of response to injected gonadotropin between the Graafian follicle and oocyte in pigs. Nature, Lond. 260, 156-158.

Lowry, O.H., Rosebrough, N.J., FARR, A.L. \& RANDALL, R.J. (1951) Protein measurement with the Folin phenol reagent. J. biol. Chem. 193, 265-275.

McNatty, K.P., Baird, D.T., Bolton, A., Chambers, P., Corker, C.S. \& Mclean, H. (1976) Concentration of oestrogens and androgens in human ovarian venous plasma and follicular fluid throughout the menstrual cycle. J. Endocr. 71, 77-85.

RICHARDS, J.S. (1975) Estradiol receptor content in rat granulosa cells during follicular development: modification by estradiol and gonadotropins. Endocrinology 97, 1174-1184.

Ritzén, E.M., French, F.S., Weddington, S.C., NAYFEH, N. \& HaNsSON, V. (1974) Steroid binding in polyacrylamide gels - quantitation at steady state conditions. J. biol. Chem. 249, 6597-6604.

TAKIKAWA, H. (1966) Binding of steroids to follicular fluid proteins. In Steroid Dynamics, pp. 217-235. Eds G. Pincus, T. Nakao \& J. F. Tait. Academic Press, New York.

Tomarelli, R.M., Charney, J. \& Harding, M.L. (1949) Use of azoalbumin as substrate in colorimetric determination of peptic and tryptic activity. J. Lab. clin. Med. 34, 428-433.

Received 24 November 1976 